\title{
Diet May Be the Most Relevant Feature for the Success of Urate Lowering Therapy in Gout
}

\author{
Nimet Bilge Kalkan', Mehmet Engin Tezcan² \\ ${ }^{1}$ University of Health Sciences, Kartal Dr. Lutfi Kirdar Training and Research Hospital, \\ Department of Family Medicine, Istanbul, Turkey \\ ${ }^{2}$ University of Health Sciences, Kartal Dr. Lutfi Kirdar Training and Research Hospital \\ Department of Rheumatology, Istanbul, Turkey
}

\begin{abstract}
SUMMARY
Hyperuricemia and chronic deposition of monosodium urate crystals are the main cause of the gout. Urate lowering therapy (ULT) is the mainstay of chronic gout treatment. In this study, we evaluated demographic features and disease properties of the patients that would relate with the success of ULT.

Sixty-six gout patients on pharmacologic ULT were enrolled in the study. Non-adherence to pharmacologic ULT was an exclusion criterium. Demographic and therapeutic features and co-illnesses and disease features of the patients were obtained during the study. Then, we compared these parameters between the patients with successful ULT and inadequate ULT.

Adherence to diet was found different between the groups (OR, 7.00; CL\%95 2.27-21.56). All other features including maximum allopurinol dosage were similar.

We found that diet was the only factor that relate with success of ULT, while patients were on pharmacologic ULT. Non-adherence to both pharmacologic and non-pharmacologic measures is the main problem during ULT. Therefore, clinicians should emphasize the importance of all segments of ULT, including diet with informing patients during visits about the nature of disease and benefits of ULT.
\end{abstract}

Key words: gout, urate lowering therapy, diet, allopurinol

Corresponding author:

Mehmet Engin Tezcan

e-mail:engintez@yahoo.com 


\section{INTRODUCTION}

Gout is one of the most frequent forms of arthritis in the adult population. Chronic deposition of monosodium urate crystals, in case of hyperuricemia, is the main cause of the disease (1). Furthermore, lowering uric acid to the targeted levels is the main therapeutic objective in chronic gout treatment. Herein, uric acid should be lowered to at least $6 \mathrm{mg} / \mathrm{dL}$ according to ACR 2012 gout treatment guideline. Meanwhile, uric acid target level has been accepted as $5 \mathrm{mg} / \mathrm{dL}$ in chronic tophaceaus gout as well (2). Several factors may be associated with increased uric acid levels, including genetic factors (3); serum urate elevating drugs such as low dose acetyl salicylic acid, diuretics, beta blockers, angiotensin-converting enzyme inhibitors and angiotensin receptor blockers other than losartan (4); co-morbid illnesses, for example chronic kidney disease, metabolic syndrome, hypertension, ischemic heart disease, hyperlipidemia, diabetes and lifestyle of the patient such as diet (5). Therefore, uric acid lowering treatment (ULT) has three main directions: practicing lifestyle modifications, administering urate lowering drugs (pharmacologic ULT), and targeting co-morbid illnesses (2). Thus, patients' medical and therapeutic properties may have a role in successful ULT.

In this study, we evaluated the demographic and therapeutic properties, co-illnesses and disease features of the patients that would relate with the success of ULT. Then, we compared these parameters between the gout patients with successful ULT and inadequate ULT.

\section{MATERIAL AND METHODS}

This was a retrospective, cross-sectional and observational study. The study population included gout patients on pharmacologic ULT for at least one visit. All patients fulfilled 2015 Gout classification criteria (6). Furthermore, patients that had no pharmacologic ULT indication according to 2012 American College of Rheumatology (ACR) Guidelines for Management of Gout (2) and patients not adherent to ULT were excluded. The main outcome (successful ULT) of the study was lowering serum uric acid levels to the targeted levels stated in the 2012 ACR guideline with ULT. The patients were divided into two groups according to the outcome as successful ULT and inadequate ULT. Then, we compared the groups for undermentioned features for evaluating the factors that would relate with ULT success. Withn one year, 284 gout patients visited our rheumatology outpatient clinic. We enrolled 66 of 284 gout patients to the study who matched our inclusion criteria. We obtained demographic (gender, age, smoking, drinking habit, family gout history and body mass index) and therapeutic features (start time of ULT after diagnosis, initial and maximum dosages of the medications for ULT, other medications for co-illnesses, diet adherence, corticosteroid requirement and clinicians ULT strategies); co-illnesses and disease features (time to diagnosis, length of follow-up, patients' adherence to appointments, gout attack frequencies before and during treatment, uric acid level at diagnosis and the last visit, maximum uric acid levels, the type of chronic gout arthritis and occurrence of tophi and erosions) from patients' medical files. Furthermore, the levels of transaminases, creatinine, hemoglobin, platelet, white blood cell, serum uric acid (SUA), C-reactive protein (CRP) and erythrocyte sedimentation rate (ESR) at the last visit were obtained from the hospital's medical database. The only ULT medication available in Turkey at the time of the treatment was allopurinol. Other xanthine oxidaze inhibitor febuxostat could be exported in special circumstances, whereas uricosuric probenesid and pegloticase were unavailable. Tophies were detected during physical examination. Also, erosions were located on X-ray during visits. Moreover, the types of chronic gout arthritis were classified according to the number of affected joints and tophi as mild, moderate and severe (2). In our rheumatology outpatient clinic, gout patients are scheduled for quarterly visit during a year. In every visit, clinicians inquired about patient's medication and diet adherence. Herein, the patients were considered adherent to medication or diet if they reported that they were on treatment more than $80 \%$ of the days and visits (7). Moderate alcohol consumption (up to 1 drink per day for women and up to 2 drinks per day for men) was an accepted cut off value to classify patients as having positive drinking habit (8). During our first visit, we prescribed a formal diet to the gout patients. This diet was constituted in compliance with 2012 American College of Rheumatology Guidelines for Management of Gout (2). Furthermore, in every visit, we discussed the diet with the patients. 
This study was approved by the Local Research Ethics Committee and carried out in compliance with the Helsinki Declaration. All the patients gave written informed consent.

\section{Statistical analyses}

Statistical analyses were carried out using SPSS Version 17.0 (SPSS Inc., Chicago, IL, USA). We compared continuous variables between patients with successful and inadequate ULT by Mann-Whitney U test. The comparisons of the categorical variables were performed by using Chi-square test between the groups. The results are given as mean \pm standard deviation and a $p$ value lower than 0.05 was considered as statistically significant.

\section{RESULTS}

The number of patients with successful ULT was $32(48.4 \%)$. Only diet adherence was found statistically different between the groups $(p<0.001)$. Successful ULT group was more adherent to the diet (OR, 7.00; CL\%95 2.27 - 21.56). As expected, the SUA at the last visit was also statistically different $(\mathrm{p}<0.001)$. Other demographic, disease and treatment features

Table 1. Demographic properties, therapeutic features and laboratory values of the patients

\begin{tabular}{|c|c|c|c|}
\hline & $\begin{array}{l}\text { Successful } \\
\text { ULT } n=32\end{array}$ & $\begin{array}{l}\text { Inadequate } \\
\text { ULT } n=34\end{array}$ & $\mathbf{P}$ \\
\hline Gender $(\mathrm{M} / \mathrm{F})$ & $29 / 3$ & $28 / 6$ & 0.47 \\
\hline Age & $60.3 \pm 13.1$ & $55.8 \pm 11.8$ & 0.14 \\
\hline Body mass index & $27.2 \pm 9.8$ & $27.8 \pm 8.9$ & 0.32 \\
\hline Smoking n (\%) & $2(6.3)$ & $4(11.8)$ & 0.67 \\
\hline Drink habit n $(\%)$ & $1(2.9)$ & 0 & $\mathrm{~N} / \mathrm{A}$ \\
\hline Family history $\mathrm{n}(\%)$ & $1(2.9)$ & 0 & $\mathrm{~N} / \mathrm{A}$ \\
\hline \multicolumn{4}{|l|}{ Co-illnesses } \\
\hline Diabetes mellitus n (\%) & $7(21.9)$ & $11(32.4)$ & 0.24 \\
\hline Hypertension $\mathrm{n}(\%)$ & $19(59.4)$ & $18(52.8)$ & 0.39 \\
\hline Chronic cardiac disease* $\mathrm{n}(\%)$ & $9(28.1)$ & $6(17.6)$ & 0.23 \\
\hline Hyperlipidemia n (\%) & $1(3.1)$ & $2(5.9)$ & 0.52 \\
\hline Chronic kidney disease $\mathrm{n}(\%)$ & $6(18.8)$ & $3(8.8)$ & 0.20 \\
\hline Nephrolithiasis n (\%) & $1(3.1)$ & $2(5.9)$ & 0.52 \\
\hline \multicolumn{4}{|l|}{ Medications } \\
\hline ACE inhibitors /AT-II blockers n (\%) & $18(56.3)$ & $13(38.2)$ & 0.14 \\
\hline Beta-blockers n (\%) & $5(15.6)$ & $4(11.8)$ & 0.72 \\
\hline Diuretics n (\%) & $5(15.6)$ & $5(14.7)$ & 0.91 \\
\hline Acetylsalicylic acid n (\%) & $5(15.6)$ & $3(8.8)$ & 0.46 \\
\hline \multicolumn{4}{|l|}{ Laboratory parameters } \\
\hline Hemoglobin $(\mathrm{g} / \mathrm{dL})$ & $13.0 \pm 1.8$ & $13.5 \pm 1.8$ & 0.33 \\
\hline WBC $\left(10^{3} / \mathrm{mm}^{3}\right)$ & $7.4 \pm 1.9$ & $7.5 \pm 1.8$ & 0.85 \\
\hline Platelet $\left(10^{3} / \mathrm{mm}^{3}\right)$ & $241.7 \pm 61.9$ & $219.0 \pm 43.1$ & 0.08 \\
\hline $\mathrm{ALT}(\mathrm{U} / \mathrm{L})$ & $39.4 \pm 33.6$ & $35.2 \pm 20.6$ & 0.53 \\
\hline AST (U/L) & $35.5 \pm 13.0$ & $33.5 \pm 6.6$ & 0.42 \\
\hline Creatinine (mg/dl) & $1.10 \pm 0.2$ & $1.06 \pm 0.1$ & 0.55 \\
\hline $\mathrm{ESR}(\mathrm{mm} / \mathrm{h})$ & $25.3 \pm 17.8$ & $19.5 \pm 10.3$ & 0.12 \\
\hline CRP (mg/L) & $6.14 \pm 4.1$ & $4.4 \pm 2.1$ & 0.06 \\
\hline
\end{tabular}

M, Male; F, Female ACE, Angiotensin-converting enzyme; AT-2, Angiotensin-II receptor; WBC, White blood cell; ALT, Alanine transaminase; AST, Aspartate transaminase; CRP, C-reactive protein; ESR, erythrocyte sedimentation rate ${ }^{*}$ Chronic heart failure or coronary artery disease 
Table 2. Disease and treatment features of the patients

\begin{tabular}{l|c|c|c}
\hline \hline & $\begin{array}{c}\text { Successful } \\
\text { ULT } \mathbf{n}=\mathbf{3 2}\end{array}$ & $\begin{array}{c}\text { Inadequate } \\
\text { ULT } \mathbf{n}=\mathbf{3 4}\end{array}$ & $\mathbf{P}$ \\
\hline & & & \\
\hline Time to diagnosis (month) & $58.0 \pm 62.9$ & $55.9 \pm 70.1$ & 0.94 \\
\hline Attack frequency before diagnosis (n/year) & $3.4 \pm 3.7$ & $4.5 \pm 5.1$ & 0.24 \\
\hline Attack frequency during treatment (n/year) & $0.8 \pm 2.4$ & $0.9 \pm 2.3$ & 0.28 \\
\hline Length of follow-up (month) & $12.1 \pm 15.1$ & $14.1 \pm 17.0$ & 0.41 \\
\hline Pretreatment SUA (mg/dL) & $9.47 \pm 1.6$ & $8.8 \pm 1.6$ & 0.18 \\
\hline Maximum SUA after diagnosis (mg/dL) & $9.2 \pm 1.8$ & $9.0 \pm 1.4$ & 0.83 \\
\hline SUA at last visit (mg/dL) & $5.2 \pm 0.7$ & $7.9 \pm 1.2$ & $<\mathbf{0 . 0 0 1}$ \\
\hline Number of visits (n/year) & $1.7 \pm 0.7$ & $1.6 \pm 0.6$ & 0.46 \\
\hline Maximum allopurinol dosage (mg) & $290.6 \pm 92.8$ & $313.8 \pm 134.8$ & 0.75 \\
\hline Adherence to diet $\mathrm{n}(\%)$ & $26(81.2)$ & $13(38.2)$ & $<\mathbf{0 . 0 0 1}$ \\
\hline Chronic gout arthritis n (\%) & $8(25.0)$ & $11(32.3)$ & 0.56 \\
\hline Mild & $7 / 8$ & $8 / 11$ & \\
\hline Moderate & $0 / 8$ & $2 / 11$ & \\
\hline Severe & $1 / 8$ & $1 / 11$ & \\
\hline Tophus $\mathrm{n}(\%)$ & $5(15.6)$ & $2(5.8)$ & 0.25 \\
\hline Erosion $\mathrm{n}$ (\%) & $7(21.8)$ & $7(20.5)$ & 1.00 \\
\hline Increasing allopurinol dosage due to high SUA* & $12(37.5)$ & $19(55.8)$ & 0.46 \\
\hline \hline
\end{tabular}

SUA, serum uric acid

* At least one time during visits

$\mathrm{P}<0.05$ is presented in bold

and frequencies of co-illnesses of the patients were similar between the groups (Table 1 and 2). At the last visit, all patients were on allopurinol. Even though more than half of the clinicians preferred to increase the allopurinol dosages prescribed to the patients in inadequate ULT group for achieving uric acid targets, the median maximum allopurinol dosage between the groups was similar $(p=0.75)$. In both groups, median allopurinol dosage was $300 \mathrm{mg}$. Moreover, none of the clinicians preferred to start febuxostat. Furthermore, the frequency of gout attacks after starting chronic gout treatment was also similar $(p=0.28)$. It was noteworthy that even though the patients were scheduled quarterly visits, both groups appointed the visits less than twice a year.

\section{DISCUSSION}

In this study, we focused on the factors that may affect the success of ULT in the gout patients who were adherent to pharmacologic treatment. The result of the study may have emphasized the supportive role of the diet in the overall success of the ULT. Also, once again, we showed the tendency for under-dosing of allopurinol. Both co-morbid illness and drugs that related with hyperuricemia and features of disease were not found to be related with successful ULT.

Pharmacologic and non-pharmacologic approaches should be implemented simultaneously for effective ULT (9).

Pharmacologic ULT depends on different pathways that constantly increase. Currently, xanthine oxidase inhibition, uricosuria, urate oxidation (10) and urate reabsorption channel inhibition (11) are the most frequently used pathways. Both ACR 2012 (2) and European League against Rheumatology 2016 guidelines (12) advise xanthine oxidase inhibitors, especially allopurinol and uricosuric drugs as first line treatment. In refractory cases, clinicians were recommended to use a combination of xanthine oxidase inhibitors with uricosuric drugs or urate oxidase enzyme. Therefore, increasing options give important strength to the clinicians for the 
success of ULT. Depending on the availability, clinicians should use alternative options. Unfortunately, during our study period, allopurinal was the only drug that could be found without special procedures. Therefore, all patients were on allopurinol throughout the study.

Poor adherence (13) and underdosing are the main causes of unsuccessful pharmacologic ULT (14). In our study, one of the exclusion criteria was non-adherence to ULT. Herein, even though more than half of the clinicians preferred to increase allopurinol dosages when SUA was found higher than targeted levels in the inadequate group, maximum allopurinol dosages between successful and inadequate ULT group were still similar. Therefore, we may say that allopurinol underdosing would be an ongoing problem in pharmacologic ULT. This finding was also compatible with European data (15). Moreover, in successful ULT group, even though less than half of the clinicians increased allopurinol dosages when SUA was found higher than targeted levels, most patients reached the targeted SUA levels. This might also be due to diet's supportive role for successful ULT.

Non-pharmacologic methods were diet, targeting co-morbid illness and life style modifications (2). As poor adherence and underdosing of ULT medications are so frequent problems, effective diet may have the key role for reaching targeted SUA. The Dietary Approaches to Stop Hypertension (DASH) diet was found to diminish SUA by 0.8 to 1 $\mathrm{mg} / \mathrm{dL}$, if the pretreatment SUA was higher than 6 $\mathrm{mg} / \mathrm{dL}$ (16). Also, Dessein et al. showed that effective diet decreased the level of SUA from $10.2 \mathrm{mg} / \mathrm{dl}$ to $8.4 \mathrm{mg} / \mathrm{dL}$ (17). We showed that under pharmacologic ULT, The diet relevant in ACR 2012 gout guideline might be the key factor for successful ULT. Moreover, effective diet might lower the ULT medications dosages needed to reach the targeted SUA, decrease the frequency of attacks (18) and treat other co-morbidities (19). According to the results of this study, diet would be more important especially for patients with non-adherence to pharmacological treatment or those with inherited resistance to the drugs.

There are also some barriers for the successful diet therapy in gout patients. In Turkey, except rheumatologist, less than half of the clinicians recommend appropriate diet for their gout patients (20). Furthermore, in a study, less than half of the patients were found to adhere to the advised diet (21). In our study, even if we emphasized the importance of the diet in every visit, 39 (\%59.0) of 66 patients were adherent to the treatment. Education of patients with explaining the causes of gout and emphasizing the benefits of diet and the pharmacologic treatments may improve the adherence of patients to the treatments (22).

This study had some limitations. Firstly, due to a limited number of patients it was an underpowered study. However, this would not reduce the importance of our findings that showed the efficacy of diet for effective ULT. Also, in both groups, the median allopurinol dosage was similar. Secondly, allopurinol was the only ULT medication that was used during the study period. Lastly, we could only check the patients' adherence to the diet through self-reporting.

As a consequence, diet therapy is an essential part of effective ULT. It may be helpful both in reaching the targeted SUA, treating co-morbidities and reducing attack frequency. Unfortunately, adherence is the most important problem for the effective diet. One of the main approaches for successful ULT should be the education of patients about both the nature of gout and importance of diet in gout. This approach may improve the adherence of patients to both pharmacologic/non-pharmacologic measures and eventually increase the success rate of ULT.

\section{Acknowledgements}

None 


\section{References}

1. Dalbeth N, Merriman TR, Stamp LK. Gout. Lancet 2016;388:2039-52.

https://doi.org/10.1016/S0140-6736(16)00346-9

2. Khanna D, Fitzgerald JD, Khanna PP et al. 2012 American College of Rheumatology guidelines for management of gout. Part 1: systematic nonpharmacologic and pharmacologic therapeutic approaches to hyperuricemia. Arthritis Care Res (Hoboken) 2012;64:1431-46.

https://doi.org/10.1002/acr.21772

3. Merriman TR. An update on the genetic architecture of hyperuricemia and gout. Arthritis Res Ther 2015;17:98.

https://doi.org/10.1186/s13075-015-0609-2

4. Reyes AJ. Cardiovascular drugs and serum uric acid. Cardiovasc Drugs Ther 2003;17:397-414. https://doi.org/10.1023/B:CARD.0000015855.02485.e3

5. Bardin T, Richette P. Impact of comorbidities on gout and hyperuricaemia: an update on prevalence and treatment options. BMC Med 2017;15:123.

https://doi.org/10.1186/s12916-017-0890-9

6. Neogi T, Jansen TL, Dalbeth N, et al. 2015 Gout Classification Criteria: an American College of Rheumatology/European League Against Rheumatism collaborative initiative. Arthritis Rheumatol 2015;67:2557-68. https://doi.org/10.1002/art.39254

7. Hansen RA, Kim MM, Song L, at al. Comparison of methods to assess medication adherence and classify nonadherence. Ann Pharmacother 2009;43:413-22.

https://doi.org/10.1345/aph.1L496

8. Available from:

https://health.gov/dietaryguidelines/2015/guidelin es/appendix-9/.
9. Choi HK. A prescription for lifestyle change in patients with hyperuricemia and gout. Curr Opin Rheumatol 2010;22:165-72.

https://doi.org/10.1097/BOR.0b013e328335ef38

10. Guttmann A, Krasnokutsky S, Pillinger MH,Berhanu A. Pegloticase in gout treatment safety issues, latest evidence and clinical considerations. Ther Adv Drug Saf 2017;8:379-88. https://doi.org/10.1177/2042098617727714

11. Abhishek A. New urate-lowing therapies. Curr Opin Rheumatol 2017;

12. Richette P, Doherty M, Pascual E, et al. 2016 updated EULAR evidence-based

recommendations for the management of gout. Ann Rheum Dis 2017;76:29-42.

https://doi.org/10.1136/annrheumdis-2016-209707

13. Scheepers L, Van Onna M, Stehouwer CDA, at al. Medication adherence among patients with gout: A systematic review and meta-analysis. Semin Arthritis Rheum 2018;47(5):689-702;

https://doi.org/10.1016/j.semarthrit.2017.09.007

14. Stamp LK, Merriman TR, Barclay ML, et al. Impaired response or insufficient dosage? Examining the potential causes of "inadequate response" to allopurinol in the treatment of gout. Semin Arthritis Rheum 2014;44:170-4. https://doi.org/10.1016/j.semarthrit.2014.05.007

15. Khanna P, Hagerty D, Mischler R,Morlock R. Adherence to EULAR recommendations for the treatment of gout. Ann Rheum Dis 2012;71(Suppl 3):448.

https://doi.org/10.1136/annrheumdis-2012eular.2854

16. Tang O, Miller ER, 3rd, Gelber AC, at al. DASH diet and change in serum uric acid over time. Clin Rheumatol 2017;36:1413-7. 
https://doi.org/10.1007/s10067-017-3613-x

17. Dessein PH, Shipton EA, Stanwix AE, at al. Beneficial effects of weight loss associated with moderate calorie/carbohydrate restriction, and increased proportional intake of protein and unsaturated fat on serum urate and lipoprotein levels in gout: a pilot study. Ann Rheum Dis 2000;59:539-43.

https://doi.org/10.1136/ard.59.7.539

18. Zhang Y, Chen C, Choi H, et al. Purine-rich foods intake and recurrent gout attacks. Ann Rheum Dis 2012;71:1448-53.

https://doi.org/10.1136/annrheumdis-2011-201215

19. Nickolai B, Kiss C. [Nutritional therapy of gout]. Ther Umsch 2016;73:153-8. https://doi.org/10.1024/0040-5930/a000772

20. Ozturk MA, Mercan R, Gok K, et al. The management of gout in different clinical specialties in Turkey: a patient-based survey. Clin Rheumatol 2016; 35:3019-24.

https://doi.org/10.1007/s10067-016-3423-6

21. Sheng F, Fang W, Zhang B, at al. Adherence to gout management recommendations of Chinese patients. Medicine (Baltimore) 2017;96:e8532. https://doi.org/10.1097/MD.0000000000008532

22. Abhishek A, Doherty M. Education and nonpharmacological approaches for gout. Rheumatology (Oxford) 2018;57:i51-i58. https://doi.org/10.1093/rheumatology/kex421 


\title{
Režim ishrane može biti najvažni segment u terapiji uspešnog snižavanja urata kod gihta
}

\author{
Nimet Bilge Kalkan¹, Mehmet Engin Tezcan² \\ ${ }^{1}$ Univerzitet zdravstvenih nauka, Bolnica za obuku i istraživanje Kartal Dr. Lutfi Kirdar, \\ Departman za porodičnu medicinu, Istanbul, Turska \\ ${ }^{2}$ Univerzitet zdravstvenih nauka, Bolnica za obuku i istraživanje Kartal Dr. Lutfi Kirdar, \\ Departman za reumatologiju, Istanbul, Turska
}

\section{S A ŽETAK}

Hiperurikemija i hronično taloženje kristala natrijum urata glavni su uzrok gihta. Terapija snižavanja urata osnova je u lečenju gihta. U ovoj studiji ispitivane su demografske osobine i karakteristike oboljenja, koje bi mogle biti povezane sa uspešnijim snižavanjem urata.

U studiji je učestvovalo šezdeset šest bolesnika, koji su bili na farmakološkoj terapiji snižavanja urata. Nepridržavanje farmakološkoj terapiji bio je kriterijum za isključenje iz studije. Demografske i terapeutske karakteristike, kao i karakteristike udruženih bolesti i gihta, prikupljene su za potrebe studije. Nakon toga, uporedili smo parametre između bolesnika na uspešnoj terapiji snižavanja urata i bolesnika na neadekvatnoj terapiji.

Pridržavanje dijeti razlikovalo se između grupa (OR, 7,00; CL\%95 2,27 - 21,56). Sve ostale karakteristike, uključujući i dozu alopurinola, bile su slične.

Utvrdili smo da je režim ishrane jedini faktor koji se povezuje sa uspešnim snižavanjem urata, dok su bolesnici bili na farmakološkoj terapiji snižavanja urata. Nepoštovanje farmakoloških i nefarmakoloških mera bilo je glavni problem za vreme terapije snižavanja urata. Stoga, kliničari bi trebalo da naglase značaj svih segmenata terapije snižavanja urata, uključujući i režim ishrane, uz obavezno informisanje bolesnika o prirodi bolesti i benefitima terapije snižavanja urata.

Ključne reči: giht, terapija snižavanja urata, režim ishrane, alopurinol 